\title{
Mulher e Educação: a Paixão pelo Possível
}

ALMEIDA, Jane Soares de. Mulher e Educação: a Paixão pelo Possível. São Paulo: Editora UNESP, 1998.

\author{
Alinne Felipe da Silva Monteiro ${ }^{1}$ \\ Cleide Furtado dos Santos ${ }^{2}$
}

\begin{abstract}
$* * *$
"A autora opera um bem articulado resgate do exercício docente das professoras, requalificando-o ante tantas críticas, aleivosias e estereótipos que perpassam a cultura brasileira.” ALMEIDA, 1998, (p.13)
\end{abstract}

O livro é uma pesquisa historiográfica sobre as condições das primeiras professoras dos cursos de magistério, das antigas escolas normais. O livro analisa o quadro histórico da atuação das mulheres no processo educacional brasileiro, mostrando relatos de três mulheres da década de 40 e 50, fazendo comparativo com os progressos que ocorreram desde o tempo em que as mulheres conseguiram dar o primeiro passo para obterem alguma instrução para ingressar no campo profissional.

Apesar da pretensão de igualdade, ela somente funcionava na teoria pois na prática era uma situação totalmente diferente, a sociedade não pretendia abrir tamanho espaço para as mulheres, o discurso era o mesmo, que o trabalho intelectual as tiraria do espaço feminino, onde elas deveriam somente se preocupar com o lar e a família. "Na realidade, o fim último da

\footnotetext{
1 Graduanda em Pedagogia pela Universidade Federal do Amazonas (UFAM). E-mail: alinne.fsm@gmail.com

2 Graduanda em Pedagogia pela Universidade Federal do Amazonas (UFAM). E-mail: cleidefurtado@gmail.com
} 
educação era preparar a mulher para atuar no espaço doméstico e incumbir-se do cuidado com o marido e os filhos, não se cogitando que pudesse desempenhar uma profissão assalariada”. (p.19)

A mulher sempre foi vitimizada pela sociedade, conhecida como sexo frágil, a que deveria ser protegida e cuidada por um homem, que primeiramente seria o pai e depois essa responsabilidade passaria para o marido, essa questão sempre teve grande peso na vida das mulheres, peso esse que influenciou muito na vida profissional delas pois a sociedade não acreditava na capacidade profissional que elas detinham.

Quando incorporaram o magistério a ser um trabalho de essência feminina, algumas teorias colocaram como esse fator se devesse ao fato da desvalorização da profissão, o que acarreta outro ponto da vitimização que a sociedade impôs a mulher.

A questão do magistério ser uma profissão essencialmente feminina abre preceitos que a sociedade colocou na mulher, como se seguir a profissão de professora fosse um ato nobre, de missão, de servir ao próximo. A autora fala em um trecho sobre a educação ser uma paixão pelo o possível "Este termo exibe uma ambiguidade que não deve ser confundida com missão, vocação ou sacerdócio, qualificações profissionais que estiveram em voga na época à qual me refiro e que hoje parecem estar superadas.” ( p.21)

Esses preceitos que a sociedade colocou na profissão do magistério apesar de ser preconceituosa, foi um ponto para as mulheres conseguirem trabalhar com o magistério pois era socialmente aceito que a mulher fosse professora pois a profissão recebeu esse ar de maternidade e devoção e não fugia dos contornos de feminilidade, como outras profissões poderiam fazer. "Durante muito tempo a profissão de professora foi praticamente a única em que as mulheres puderam ter o direito de exercer um trabalho digno e conseguir uma inserção no espaço público, dado que os demais campos profissionais lhes foram vedados". (p.23)

"Manter o dominado longe do saber foi e continua sendo uma estratégia eficiente no controle e na manutenção de mecanismos de dominação.” (p.31). Como 
os homens que cuidavam da educação da mulher, manter elas longe das escolas dava a eles mais controle sobre a vida delas pois elas iriam continuar vivendo sob os interesses do que a sociedade esperava, que era aguardar o casamento e não concorrer com o homem para não ultrapassa-lo e fazer ele se sentir inferior ao ter o seu intelecto igual ao de uma mulher.

A autora aborda também sobre a feminização do magistério e pontua como a desvalorização salarial da carreira docente já ocorria antes mesmo das mulheres serem inseridas neste meio profissional, culpar as mulheres por algo que já possuía seu contexto histórico só fortalece a desvalorização do gênero feminino no âmbito profissional.

Com a inserção da mulher na carreira docente, houve o fortalecimento de certos atributos para o exercício da profissão do magistério, como “[...]atributos de amor, respeito, vocação e competência[...]” (Jane, 1998, p.81), contudo vale ressaltar que ter conhecimento adequado também era e continua sendo de suma importância para se exercer a docência, além de técnicas e embasamento teórico, se as mulheres daquela época se tornaram profissionais da educação foi porque eram qualificadas para o cargo, apesar da sociedade desmerece-las.

Quando a história das mulheres começou a ser contada, quem as narrava eram os homens, eles fundaram revistas femininas que somente a minoria dos funcionários eram realmente mulheres, muitos criavam até pseudônimos femininos para escrever nas colunas e assim pregar o tradicionalismo, contudo não demorou muito para que as mulheres das classes altas começassem a fundar as suas próprias revistas e assim os periódicos se tornaram verdadeiramente femininos e feministas.

É citado no livro a metodologia da história oral, tal metodologia foi utilizada pela autora em conjunto com a categoria de analise da memória durante as entrevistas com as 3 professoras aposentadas, que contaram suas histórias pessoais, sobre as suas vivencias durante o magistério, como os costumes nos quais elas foram criadas e educadas sofreram mudanças até os 
dias atuais, além de seus relatos de como era ser uma mulher em uma sociedade extremamente patriarcal, conservadora e machista.

O livro proporcionou um embasamento maior sobre a história das mulheres, sobre os preconceitos enfrentados, como eram socialmente tratadas, as suas lutas e conquistas, como foi o processo de escolarização das mulheres e o surgimento de oportunidades profissionais que antes eram inimagináveis, a autora Jane Soares de Almeida relatou muito bem todo esse processo histórico, obrigada Jane Soares por contribuir para a história das mulheres.

Recebido em janeiro de 2021. Aprovado em março de 2021. 